\title{
Aplikasi Penjualan Tiket Kelas Pelatihan Berbasis Mobile menggunakan Flutter
}

\author{
http://dx.doi.org/10.28932/jutisi.v5i3.1865
}

\author{
Filian Enggar Krisnada ${ }^{\# 1}$, Radius Tanone ${ }^{凶 * 2}$ \\ \#Jurusan Teknik Informatika, Universitas Kristen Satya Wacana \\ Jl. Dr. O Notohamidjojo, Kel.Blotongan, Kec. Sidorejo, Salatiga \\ ${ }^{1}$ filianenggaregmail.com \\ *Jurusan Teknik Informatika, Universitas Kristen Satya Wacana \\ Jl. Dr. O Notohamidjojo, Kel.Blotongan, Kec. Sidorejo, Salatiga \\ ${ }^{2}$ radius. tanoneauksw. edu
}

\begin{abstract}
Pincher is an online platform that is useful for assisting in finding and registering for training classes aimed at facilitating users who want to find their identity and channel their talents and inspirations creatively. This pincher application provides information and distributes training classes by selling class tickets. In its development as an online platform, Pincher still uses the website as a means of distributing training classes owned by Pincher, so this tool is less effective and efficient for users because the Pincher website is too complicated to access using a mobile phone or smartphone. Therefore, to help users access the Pincher application using their mobile phones, Pincher applications are made in a simple form that is applied to mobile applications. In addition, Pincher also does not have a feature that can make it easier for customers to determine the class to be chosen. Therefore this mobile application will be equipped with a system that can make it easier for users to choose attractive classes for customers, namely with a recommendation system.
\end{abstract}

Keywords - Ticket Selling Application; Flutter: Mobile Application; Recommendation System.

\section{Pendahuluan}

Berawal dari sebuah keprihatinan di bidang pendidikan, dimana kurang mampunya generasi muda mengikuti perkembangan global dan persaingan kerja di Indonesia, kebutuhan pendidikan atau pembelajaran yang berkualitas sangat diperlukan bagi generasi muda di era modern ini. Diambil dari Statistik Pendidikan 2015 pada bps.go.id, terdapat ketimpangan - ketimpangan pendidikan dalam rerata lama penduduk Indonesia dalam menempuh sekolah. Artinya, sistem pendidikan Indonesia belum inklusif dan akses pendidikan masih sangat terbatas. Indonesia berada di urutan 67 dari 125 negara di dunia dalam peringkat GTCI(Global Talent Competitiveness Index) 2019. Sumber daya manusia (SDM) penting untuk menjadi prioritas pemerintah. Karena daya saing SDM di Indonesia masih kalah jika dibandingkan dengan negara lain. Salah satu cara meningkatkan daya saing adalah dengan meningkatkan kualitas pendidikan di Indonesia. Berkaitan dengan cara untuk meningkatkan kualitas pendidikan tersebut, PT. Rect Media Komputindo tergerak untuk membuat terobosan yang dapat membantu masyarakat dalam mencari ilmu yaitu dengan membuat Pincher. Pincher adalah sebuah platform online yang dibangun oleh bapak Purbo Hapsara dan dikembangkan bersama agensi dari PT. RectMedia Komputindo untuk membantu masyarakat dalam mencari dan mendaftarkan diri untuk mengikuti kelas pelatihan yang bertujuan memfasilitasi masyarakat yang ingin meningkatkan kompetensi dan menyalurkan talenta secara kreatif dengan bekerjasama bersama pendidik yang berkualitas untuk memberikan inovasi dan inspirasi dalam mengembangkan talenta yang dimiliki masyarakat. Pincher mempunyai sebuah alamat web yaitu www.pincher.id.

Berkaitan dengan Pincher ini, aplikasi yang digunakan hanya menggunakan web saja, sehingga Pincher kurang efisien dalam menjangkau pelanggannya. Dengan kekurangan tersebut, maka sistem dari Pincher ini harus masuk ke dalam media yang dapat menjangkau banyak pelanggan. Berdasarkan dari wawancara dengan bapak Werdani Sulistya Hadi, S.Pd yang merupakan seorang pengembang aplikasi Pincher dari RectMedia, perancangan sistem untuk penjualan tiket kelas pelatihan atau event dari Pincher ke dalam media yang mudah dijangkau masyarakat dibutuhkan karena di era yang modern ini kemudahan dan keefisienan sangat dibutuhkan oleh masyarakat. Penggunaan perangkat mobile pada jaman sekarang sangatlah meluas, mulai dari generasi muda sampai orang tua banyak menggunakan perangkat mobile. Oleh karena itu penerapan sistem aplikasi untuk penjualan tiket kelas pelatihan ini diaplikasikan pada perangkat mobile. Aplikasi penjualan tiket kelas pelatihan juga akan dilengkapi dengan sistem rekomendasi kelas untuk memudahkan calon peserta kegiatan atau pengguna aplikasi menemukan kelas yang menarik bagi mereka. Dikutip dari jurnal Internasional yang berjudul "MSME Recommendation Application using 
Collaborative Filtering Method and Realtime Database (Case Study: Salatiga City)" sistem rekomendasi produk berdasarkan perilaku pengguna menggunakan metode Collaborative Filtering sangat berguna karena dapat memberikan hasil rekomendasi yang berbeda untuk setiap pengguna berdasarkan hasil penilaian yang telah diberikan kepada setiap produk [1]. Dengan itu maka penelitian ini menerapkan metode Collaborative Filtering untuk sistem rekomendasi kelas pelatihan.

Rumusan masalah yang terdapat pada masalah tersebut yaitu bagaimana merancang sebuah aplikasi penjualan tiket kelas pelatihan ini agar sesuai dengan standar aplikasi penjualan sehingga mudah digunakan oleh pengguna dan bagaimana membuat sistem rekomendasi kelas untuk calon peserta agar dapat membantu menemukan kelas yang terbaik. Tujuan dan manfaat dari penelitian ini adalah untuk dapat membantu memudahkan masyarakat yang mencari kegiatan pembelajaran untuk dapat menemukan kegiatannya secara praktis dan efisien dengan dibuatnya aplikasi penjualan tiket kelas pelatihan. Kemudian juga dengan adanya sistem rekomendasi, maka akan mengurangi tingkat kekecewaan dari para peserta yang telah mengikuti kelas pelatihan tersebut dan juga penyedia kelas pelatihan juga bisa tahu apa saja kelas yang paling banyak diminati oleh pelanggan sehingga penyedia kelas dapat menyediakan kelas yang lebih baik atau mengganti kelasnya dengan yang lain untuk menambah minat para pesertanya. Batasan masalah yang terdapat dalam penelitian ini adalah aplikasi yang dibuat berupa aplikasi mobile. Data yang diambil masih menggunakan database lokal, dan hanya beberapa kelas dan pengguna aplikasi yang digunakan untuk membuat sistem rekomendasi.

\section{KAJIAN PUSTAKA}

Terkait dengan penelitian dalam perancangan aplikasi penjualan atau pemesanan tiket. Penelitian yang berjudul "Sistem Informasi Pemesanan Tiket Travel Berbasis Mobile Android". Aplikasi ini dapat menampilkan jadwal keberangkatan travel pada kasus Rahayu Travel dari Selorejo - Blitar. Pemesanan dilakukan dengan menentukan tanggal keberangkatan, rute awal dan tujuan. Setelah terjadi pemesanan, kemudian kode booking diberikan untuk cek status pembayaran dan rincian keberangkatan pemesan, jika terbayar maka status pembayaran akan berubah menjadi lunas. Manfaat dari penelitian ini yaitu dapat memberikan kemudahan dan kenyamanan dalam pemesanan tiket travel pada Rahayu Travel [2].

Penelitian lainnya dengan judul "Aplikasi Pemesanan Tiket Bioskop Berbasis Mobile" menggunakan Java Android untuk membuat aplikasi yang dihubungkan web service dan web server yang menggunakan JSP dalam pembuatannya. Aplikasi ini dapat menampilkan denah tempat duduk sebuah studio/theatre dalam proses pemesanan tiket bioskop, sehingga pengguna dapat memilih nomor tempat duduk yang diinginkan. Aplikasi pemesanan tiket bioskop mobile dapat melakukan proses pemesanan tiket bioskop, dapat menampilkan informasi lokasi bioskop, harga tiket setiap bioskop, menampilkan informasi film yang sedang ditayangkan, dan menampilkan informasi film segera tayang. Manfaat dari penelitian ini adalah dapat memberikan informasi film tayang di bioskop dan membantu mempersingkat waktu yang diperlukan untuk memesan tiket bioskop [3].

Penelitian untuk sistem perekomendasian terdapat pada penelitian yang berjudul "Sistem Rekomendasi Produk Sepatu dengan menggunakan Metode Collaborative Filtering" menggunakan metode item-based Collaborative Filtering dimana masukan data awal adalah nilai rating dari pelanggan. Setelah itu dicari kemiripan antar item untuk melakukan prediksi antar item yang belum pernah di ratting sebelumnya. Menghitung kemiripan antar data menggunakan adjusted cosine similarity dan weight sum untuk prediksi antar item. Item-based Collaborative Filtering membutuhkan perhitungan yang lebih sedikit tetapi mempunyai kualitas yang sama dibandingkan dengan metode user-based [4].

Penelitian lain berjudul "Penerapan Metode Collaborative Filtering Menggunakan Rating Implisit pada Sistem Perekomendasi Pemilihan Film di Rental VCD" diimplementasikan metode collaborative filtering menggunakan rating implisit biner untuk menyediakan rekomendasi personal bagi member-member di rental VCD berupa film - film yang mungkin menarik sehingga akhirnya dapat membantu dalam proses pemilihan film film yang ingin disewa [5].

Penelitian lainnya berjudul "Aplikasi Rekomendasi Film menggunakan Pendekatan Collaborative Filtering dan Euclidean Distance sebagai ukuran kemiripan rating" dengan sistem rekomendasi untuk toko film online yang menggunakan pendekatan Collaborative Filtering dan Euclidean Distance sebagai ukuran kemiripan rating para pelanggan toko. Euclidean Distance mengukur jarak rating dari dua pelanggan, semakin kecil Euclidean Distance, maka semakin mirip rating yang diberikan kedua pelanggan tersebut begitu juga sebaliknya [6].

Pada penelitian sebelumnya tersebut dapat dilihat bahwa aplikasi pemesanan harus dapat menampilkan informasi yang baik mengenai produk yang dijual dan mudah untuk dipakai serta proses pembayaran dapat dilakukan dengan mudah dan cepat agar nyaman dan efisien untuk pengguna aplikasi. Dan juga berkaitan dengan sistem rekomendasi kelas, penelitian sebelumnya dapat dilihat bahwa metode Collaborative Filtering sangat cocok untuk diterapkan pada penelitian ini karena mempunyai kelebihan untuk menghasilkan rekomendasi berkualitas tinggi kemudian dengan menggunakan Euclideance Distance, maka jarak perbedaan dapat dihitung dengan mudah. Berdasarkan penelitian - penelitian tersebut, penelitian ini menerapkan metode Collaborative Filtering dan pendekatan Euclideance Distance sehingga menjadi nilai tambah dari aplikasi untuk 
membantu pengguna aplikasi dalam menentukan kelas pelatihan yang ingin diikuti. Pengembangan dari aplikasi ini menggunakan framework Flutter dalam membuat aplikasi sehingga aplikasi dapat dijalankan pada sistem operasi Android dan iOS. Framework Flutter digunakan untuk pembuatan aplikasi mobile dan php untuk membuat web service dan MySQL untuk mengelola local database.

Flutter adalah sebuah SDK atau framework open source yang dikembangkan oleh Google untuk membuat atau mengembangkan aplikasi yang dapat berjalan dalam sistem operasi Android dan iOS. Flutter menggunakan bahasa pemrograman Dart dalam pengkodean. Perbedaan framework Flutter dengan yang lainnya yaitu dalam build aplikasi, pada framework ini semua kodenya di compile dalam kode native-nya (Android NDK, LLVM, AOTcompiled) tanpa ada interpreter pada prosesnya sehingga proses compile-nya menjadi lebih cepat [7].

Web Service adalah sekumpulan logika aplikasi yang dibuat atau disusun untuk dijadikan layanan web bagi perangkat lain untuk mengakses sejumlah data dari database melalui internet atau intranet. Web service sebagai sekumpulan fungsi program untuk melakukan pekerjaan tertentu yang dalam hal ini tentu memanipulasi data dalam mengambil, menambahkan atau mengubah data. Web service biasa dibangun dalam format XML untuk pertukaran data. Web Service tidak memerlukan browser atau HTML karena tidak menyediakan GUI atau interface untuk pengguna [8].

Kelebihan dari web service adalah sebagai berikut:

1. Mempermudah proses pertukaran data. Web service dapat mempermudah dan mempercepat pertukaran data diantara dua aplikasi daripada harus menyesuaikan aplikasi dan database yang digunakan.

2. Lintas platform web service memungkinkan berbagai perangkat yang berbeda sistem operasi dapat saling bertukar data.

3. Language Independent sebuah web service dapat diakses menggunakan bahasa pemrograman apa saja.

4. Sebagai jembatan antara database dan aplikasi, web service memberikan koneksi untuk menghubungkan aplikasi agar dapat memanipulasi data yang ada pada database.

MySQL merupakan software RDBMS (database server) untuk membuat dan mengelola suatu database secara terstruktur dan otomatis. MySQL memberikan kemudahan untuk pengguna dalam mengelola data yang berisi informasi String (text based) dan dapat diakses secara pribadi maupun untuk umum dalam suatu web. MySQL dapat diakses oleh multi-user (banyak pengguna) dan memproses secara bersamaan serta memberikan kapasitas untuk menampung data dalam jumlah besar [9].

Sistem Rekomendasi merupakan sistem yang menggunakan teknik - teknik untuk memberikan rekomendasi atau saran tentang item (barang) yang akan berguna untuk konsumen atau pelanggan. Saran tersebut biasa berkaitan dengan proses penentuan keputusan tentang barang apa yang akan dibeli. Terdapat banyak jenis sistem rekomendasi diantaranya yang paling sering dipakai adalah metode Collaborative Filtering dan content-based filtering [10].

Collaborative Filtering merupakan proses penyaringan atau pengevaluasian item dengan menggunakan pendapat dari orang lain. Metode ini digunakan untuk mencari informasi dari perilaku di masa lampau maupun pendapat dari sekelompok pengguna yang kemudian digunakan untuk memprediksi item mana yang disukai atau menarik bagi pengguna. Rekomendasi dari Collaborative Filtering didasarkan dari kualitas barang yang telah dievaluasi oleh pelanggan lain, tidak mengandalkan konten atau isi yang mungkin menjadi indikator yang kurang tepat untuk masalah kualitas [11].

Euclidean Distance adalah perhitungan jarak dari dua buah titik Euclidean space. Euclidean space diperkenalkan oleh Euclid, seorang matematikawan dari Yunani sekitar tahun 300 B.C.E. untuk mempelajari antara sudut dan jarak. Euclidean berkaitan dengan Teorima Phytagoras dan biasa diterapkan pada 1, 2 dan 3 dimensi, tetapi juga lebih sederhana jika diterapkan pada dimensi yang lebih tinggi. Berikut adalah rumus Euclidean Distance untuk ruang berdimensi $\mathbf{n}$ :

$$
d\left(\left[x_{1}, x_{2}, \ldots, x_{n}\right],\left[y_{1}, y_{2}, \ldots, y_{n}\right]\right)=\sqrt{\sum_{i=1}^{n}\left(x_{i}-y_{i}\right)^{2}}
$$

Gambar 1 Rumus Euclidean Distance[6]

Sebagai contoh $\mathrm{x}$ dan $\mathrm{y}$ adalah nilai rating dari dua pelanggan berbeda untuk $\mathrm{n}$ (berapa) buah barang sehingga diketahui jarak nilai rating dari dua pelanggan tersebut. Semakin besar nilai dari Euclideance Distance maka jarak perbedaan akan semakin besar, semakin kecil nilai Euclideance Distance yang ditunjukkan maka jarak perbedaan semakin mirip atau semakin kecil [12].

\section{METODE PERANCANGAN}

Metode Penelitian yang digunakan pada penelitian ini adalah Research and Development (RnD). Research and Development $(R n D)$ atau penelitian dan pengembangan merupakan proses atau langkah - langkah dalam mengembangkan sebuah produk baru atau menyempurnakan produk yang sudah ada dan dapat dipertanggung jawabkan. Model yang tepat untuk penelitian pengembangan yaitu menggunakan model prosedural. Model prosedural bersifat deskriptif dan mengacu pada langkah - langkah pengembangan. Berdasarkan teori Sugiyono, langkahlangkah yang harus diikuti untuk menghasilkan produk 
meliputi tahap potensi dan masalah, pengumpulan data, desain produk, validasi desain, revisi desain produk, uji coba produk, revisi produk, uji coba pemakaian, revisi produk, dan produksi masal [13]. Penelitian pengembangan ini menggunakan prosedur penelitian pengembangan menurut teori Sugiyono. Berikut pada gambar 1 adalah langkah - langkah penelitian dan pengembangan yang digunakan.

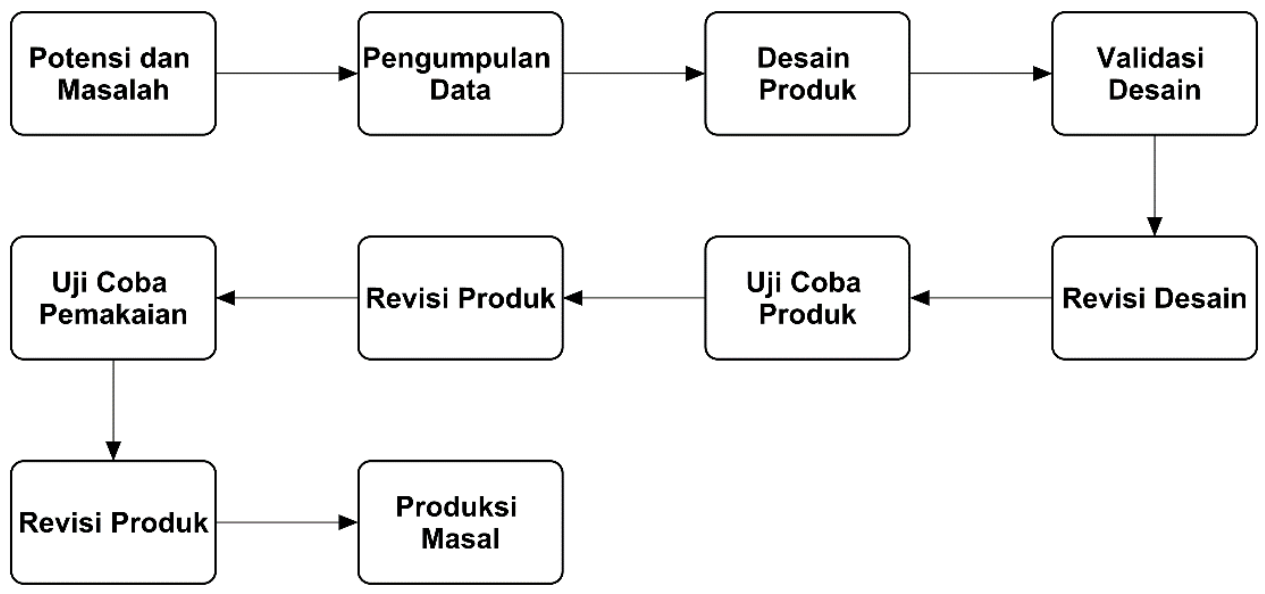

Gambar 2. Metode Penelitian [13]

Tahapan pengembangan seperti pada Gambar 2, dijelaskan sebagai berikut :

\section{Potensi dan Masalah}

Penelitian berawal dari adanya potensi dan masalah. Berdasarkan wawancara dengan bapak Werdani Sulistya Hadi, seorang pengembang aplikasi web Pincher, membahas tentang perlunya memudahkan masyarakat untuk mencari kegiatan pembelajaran. Pincher dari RectMedia masih mempunyai kekurangan untuk mempromosikan aplikasinya karena hanya menggunakan web saja. Diperlukan adanya media baru yang banyak digunakan oleh masyarakat untuk Pincher agar dapat dengan mudah dijangkau oleh masyarakat. Dengan topik tersebut maka didapatkan potensi yang dapat diangkat menjadi masalah dalam penelitian. Penelitian ini digunakan untuk membantu menjadikan Pincher sebagai media yang praktis, mudah dan dapat dijangkau oleh banyak masyarakat.

\section{Pengumpulan Data}

Pengumpulan data dilakukan dengan mengumpulkan jurnal, menjelajahi internet, wawancara dengan pihak terkait yang mengembangkan aplikasi sebelumnya, dan bacaan terkait topik, baik berupa artikel, paper, dan textbook.

\section{Desain Produk}

Desain produk didapat dari serangkaian penelitian awal. Perancangan desain produk aplikasi pemesanan tiket kelas pelatihan dirancang menggunakan UML yang meliputi use case diagram, activity diagram, class diagram, dan arsitektur sistem aplikasi.

4. Validasi Desain

Validasi desain adalah proses penilaian rancangan produk secara rasional layak digunakan oleh ahli berpengalaman. Validasi desain dalam penelitian ini dilakukan dengan meminta pendapat lewat wawancara langsung pada pengembang aplikasi Pincher.

5. Revisi Desain

Revisi desain dilakukan jika terdapat kekurangan atau kelemahan pada desain yang sudah melewati proses validasi desain. Revisi dilakukan dengan mengurangi atau menambahkan desain yang kurang sesuai.

6. Uji Coba Produk

Uji coba produk dilakukan secara terbatas. Uji coba ini dilakukan oleh pembuat aplikasi dengan mencari bug dan kekurangan secara terbatas

7. Revisi Produk

Revisi produk dilakukan apabila terdapat kelemahan dari hasil uji coba terbatas.

8. Uji Coba Pemakaian

Uji coba pemakaian dilakukan dalam kondisi nyata untuk mengetahui kelayakan aplikasi. Uji coba ini dapat dilakukan dengan melakukan alpha test yaitu pengujian perangkat lunak yang umum digunakan untuk menghindari cacat dan kegagalan penggunaan serta beta test yaitu pengujian yang dilakukan secara langsung pada pengguna acak untuk memvalidasi kegunaan, fungsi, kompatibilitas, dan reliabilitas dari perangkat lunak.

9. Revisi Produk

Revisi produk dilakukan apabila terdapat kekurangan dalam penggunaan terhadap hasil uji coba pemakaian. Dengan mengetahui kekurangan produk maka produk diperbaiki.

10. Produksi Masal

Produksi Masal adalah akhir dari penelitian ini dengan menghasilkan sebuah aplikasi pemesanan tiket kelas pelatihan berbasis mobile yang diharapkan dapat membantu 
memudahkan masyarakat dalam mencari kegiatan pembelajaran secara efektif dan efisien.

Use Case diagram merupakan diagram yang menjelaskan hubungan aktor dengan sub sistem yang ada pada sistem aplikasi. Dengan use case diagram, sistem dari aplikasi dapat digambarkan dengan memasukkan fungsi fungsi dari sub sistem yang bekerja dalam sebuah alur tatanan yang berguna untuk memperjelas hubungan aktor(user) dalam menjalankan sebuah sistem aplikasi. Dalam perancangan aplikasi penjualan tiket kelas pelatihan ini terdapat user sebagai client yang mengakses sistem aplikasi untuk pemesanan tiket kemudian pemesanan diteruskan ke web service dari admin yang mengelola data masuk aplikasi. Adapun use case interaksi dari user, admin dan aplikasi terdapat pada Gambar 3.

\section{$\underline{\text { Use }} \underline{\text { Case }}$}

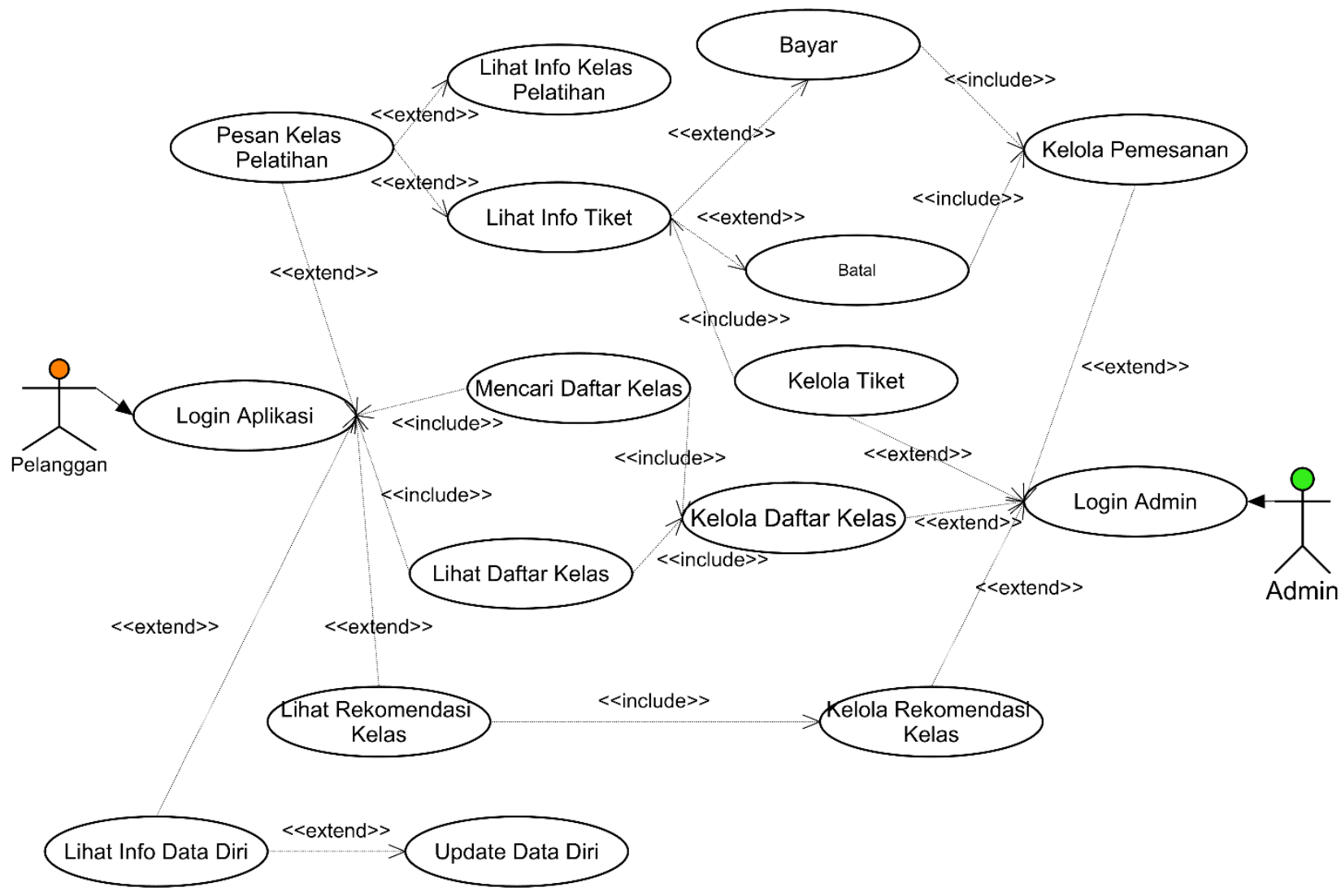

Gambar 3. Use Case Diagram Aplikasi Pemesanan Tiket Kelas

Activity diagram merupakan diagram yang menjelaskan alur proses dari interaksi pengguna dan sistem dalam aplikasi. Di dalam aplikasi penjualan tiket kelas pelatihan yang dirancang terdapat proses aktivitas yang dapat dijabarkan dari interaksi pengguna dengan aplikasi dan aplikasi dengan database server. Proses aktivitas yang penting dalam aplikasi penjualan tiket kelas ini yaitu proses registrasi member untuk dapat memesan tiket, proses pemesanan tiket kelas pelatihan dan proses untuk membatalkan pemesanan tiket kelas pelatihan. Berikut pada gambar 4 merupakan proses dari pengguna dalam melakukan registrasi pengguna untuk menjadi member. 


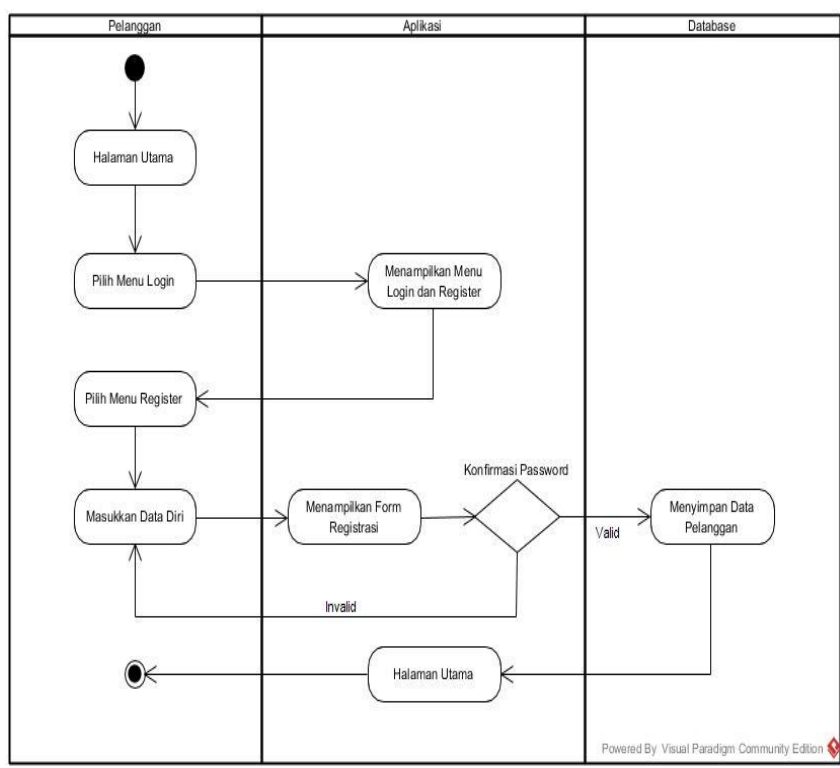

Gambar 4. Activity Diagram Proses Registrasi

Pada gambar 5 merupakan bentuk dari proses pelanggan sebagai pengguna aplikasi dalam memesan tiket kelas pelatihan. Dalam diagram ini dijelaskan pengguna melakukan login terlebih dahulu untuk dapat memesan tiket dengan alur mulai dari login, pemilihan kelas, pemesanan tiket kelas, pembayaran tiket kelas hingga mendapatkan informasi tiket yang telah dibeli.

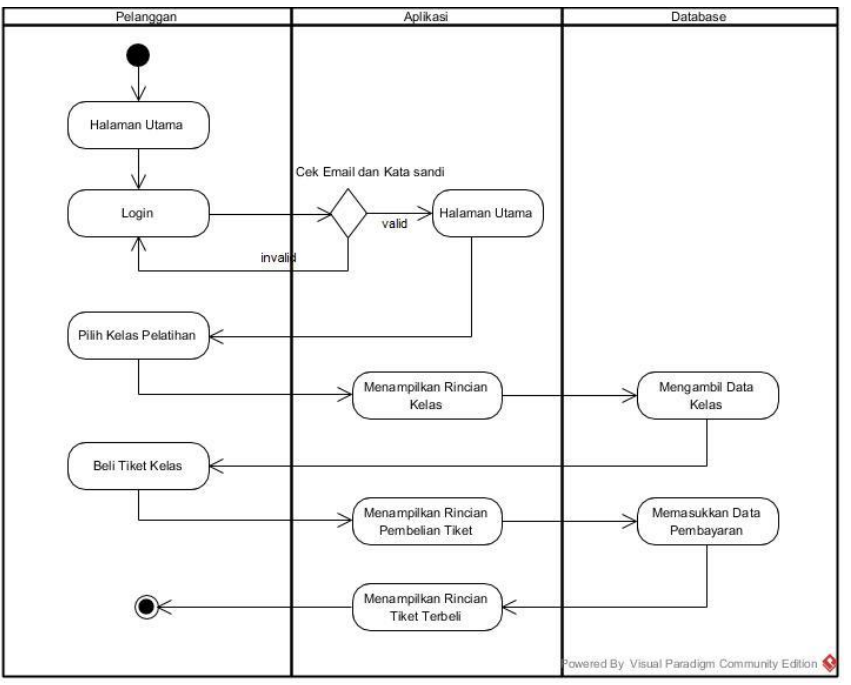

Gambar 5. Activity Diagram Pemesanan Tiket Kelas Pelatihan

Selain proses dalam pemesanan tiket pelanggan juga dapat membatalkan tiket pemesanan yang belum dibayar lewat aplikasi. Dalam proses ini dijelaskan alur dari pelanggan dari mulai login, memilih menu kelas terpesan yang akan dibatalkan, sampai pada pembatalan pemesanan tiket kelas pelatihan. Proses activity diagram pembatalan pemesanan kelas dapat dilihat pada gambar 6 .

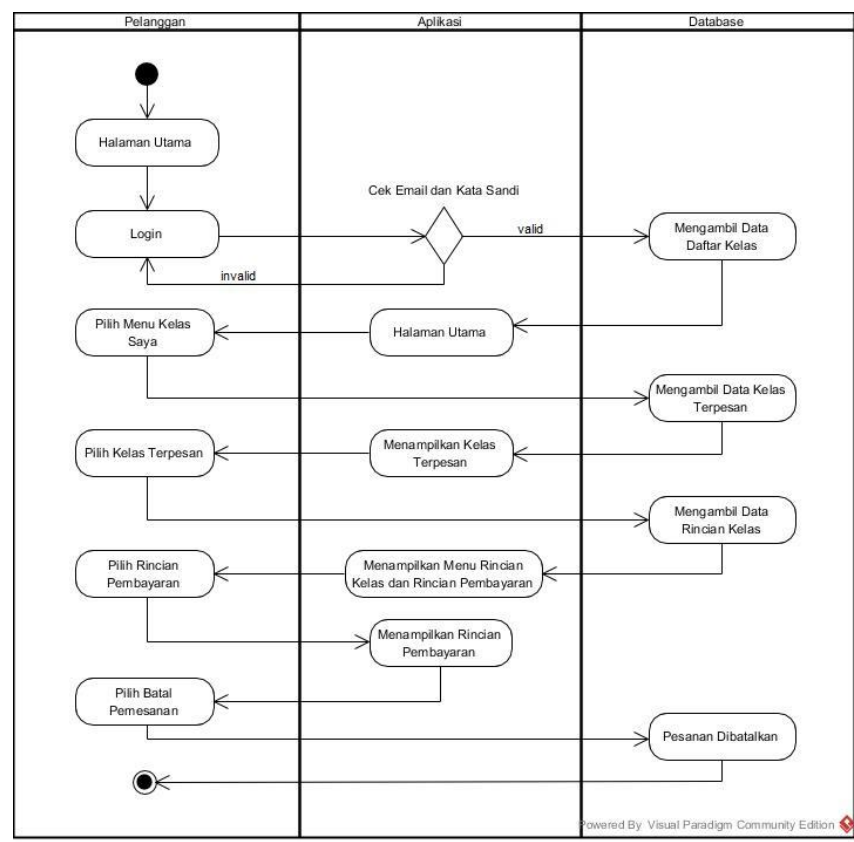

Gambar 6. Activity Diagram Pembatalan Pemesanan Tiket Kelas Pelatihan

Kemudian yang terakhir pengguna aplikasi juga dapat melihat kelas yang direkomendasikan dalam aplikasi, dengan memencet tab rekomendasi pada menu navigasi maka pelanggan akan disuguhkan halaman untuk melihat rekomendasi kelas yang ada pada aplikasi. Pada gambar 7 merupakan activity diagram dari proses untuk melihat rekomendasi kelas.

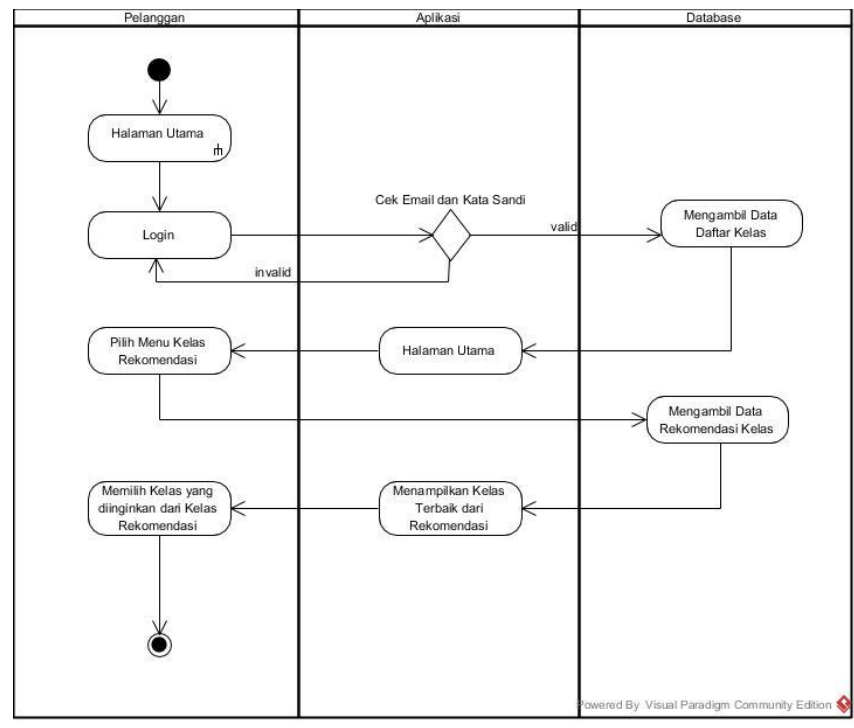

Gambar 7 Activity Diagram Cek Rekomendasi Kelas Pelatihan 
Class Dlagram

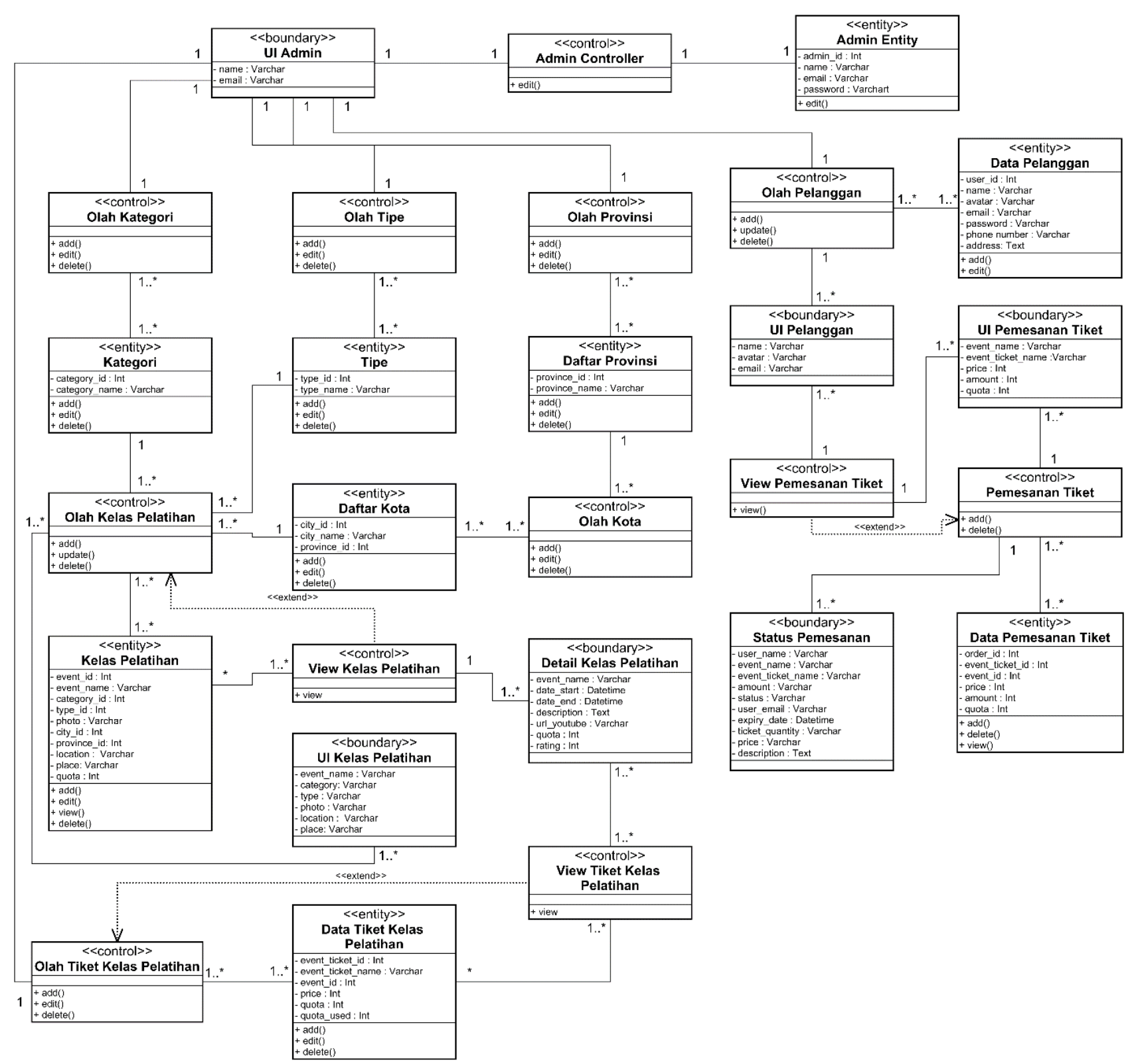

Gambar 8. Class Diagram Aplikasi Penjualan Tiket Kelas Pelatihan

Pada gambar 8 adalah class diagram Aplikasi Penjualan Tiket Kelas Pelatihan, dari gambar tersebut aplikasi memiliki 27 class dengan 9 entity class yaitu Admin Entity, Data Pelanggan, Kategori, Tipe, Daftar Provinsi, Daftar Kota, Kelas Pelatihan, Data Tiket Kelas Pelatihan, dan Data Pemesanan Tiket, 6 boundary class yaitu UI Admin, UI Pelanggan, Detail Kelas Pelatihan, UI Pemesanan Tiket, UI Kelas Pelatihan dan Status Pemesanan; dan 12 control class yaitu Admin Controller, Olah Kategori, Olah Tipe, Olah Provinsi, Olah Kota, Olah Pelanggan, Olah Kelas Pelatihan, Olah Tiket Kelas Pelatihan, View Kelas Pelatihan, View Tiket Kelas Pelatihan, View Pemesanan Tiket dan
Pemesanan Tiket. Masing - masing kelas mempunyai atribute dan behavior serta memiliki relasi antara class yang satu dengan lainnya.

Model atau arsitektur sistem aplikasi adalah desain atau rangkaian dari semua item komputer yang menggunakan teknologi informasi yang dibutuhkan untuk kemudian dipetakan ke dalam suatu organisasi yang spesifik. Aplikasi Pincher ini mempunyai beberapa item yang dibutuhkan dan dapat dipetakan ke dalam sebuah arsitektur sistem. Berikut merupakan arsitektur sistem dari aplikasi pemesanan tiket kelas pelatihan. 


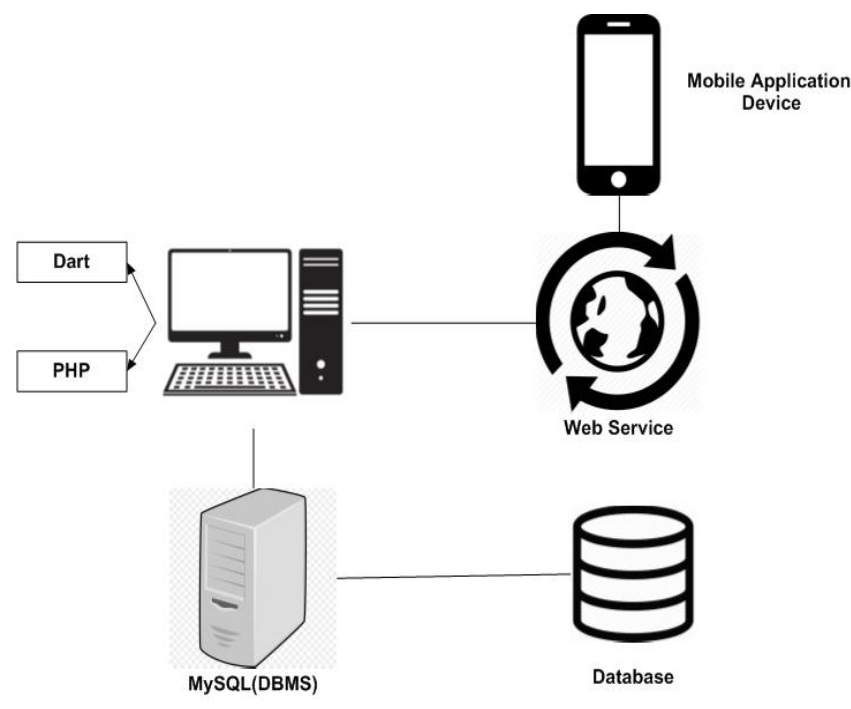

Gambar 9. Arsitektur Sistem Aplikasi Pincher

Dalam gambar arsitektur sistem tersebut dapat disimpulkan bahwa terdapat tiga modul. Modul pertama yaitu modul database yang digunakan untuk penyimpanan data. MySQL merupakan database server yang digunakan di dalam modul penyimpanan data tersebut.

Modul yang kedua yaitu modul administrator yang berguna untuk memanajemen aplikasi dan juga data. Dalam modul administrator ini, admin dapat menambah, mengubah data yang diperlukan dan menghapus data yang tidak diperlukan untuk aplikasi. Untuk mengkoneksikan database dengan aplikasi mobile diperlukan service agar dapat diakses oleh perangkat mobile tersebut, oleh karena itu administrator harus membuat web service agar perangkat lain dapat terhubung.

Terakhir yaitu modul tiga yang merupakan modul pengguna. Modul pengguna ini digunakan sebagai antarmuka pengguna dan menampilkan halaman aplikasi. Modul ini berguna untuk mengirimkan permintaan kepada web server untuk kemudian diolah dan dikirimkan kembali sebagai response dari server.

Pada bagian ini akan dijelaskan bagaimana cara menerapkan metode atau skenario dalam membuat sistem rekomendasi untuk aplikasi penjualan kelas pelatihan. Perhitungan rekomendasi ini akan dibuat dengan pendekatan Collaborative Filtering dengan Euclidean Distance untuk kemiripan rating dari pengguna. Terdapat empat pengguna yang memberikan rating kepada lima kelas pelatihan dalam aplikasi, dalam pemberian rating tersebut pelanggan ke-empat hanya memberikan rating pada dua kelas pelatihan saja. Nilai rating yang bisa diberikan dibatasi dengan nilai 1 sampai 5. Berikut adalah tabel rating dari ke-empat pelanggan pada 5 kelas pelatihan yang disediakan.
TABEL I

Rating Dari Lima Kelas Pelatihan oleh Empat Orang Pelanggan.

\begin{tabular}{|c|c|c|c|c|c|}
\hline \multirow[t]{2}{*}{ Pelanggan } & \multicolumn{5}{|c|}{ Rating Kelas } \\
\hline & $\begin{array}{c}\text { Seni } \\
\text { Batik } \\
\text { Tulis } \\
\text { (KBT) }\end{array}$ & $\begin{array}{c}\text { Latte } \\
\text { Art } \\
\text { Worksh } \\
\text { op } \\
\text { (LAW) }\end{array}$ & $\begin{array}{c}\text { Trainin } \\
\text { g X } \\
\text { Bussine } \\
\text { sS } \\
\text { (TXB) }\end{array}$ & $\begin{array}{c}\text { Tingkat } \\
\text { kan } \\
\text { Omset } \\
\text { Toko } \\
\text { Online } \\
\text { Anda } \\
\text { (OTO) }\end{array}$ & $\begin{array}{c}\text { Free } \\
\text { Traini } \\
\text { ng } \\
\text { iOS } \\
\text { (FTi) }\end{array}$ \\
\hline User 1 & 3 & 3 & 5 & 4 & 2 \\
\hline User 2 & 5 & 4 & 3 & 4 & 1 \\
\hline User 3 & 4 & 4 & 4 & 3 & 3 \\
\hline User 4 & $?$ & 3 & 4 & $?$ & $?$ \\
\hline
\end{tabular}

Dari tabel I tersebut akan dicari rekomendasi untuk pelanggan ke-empat atau user 4 dari tiga kelas yang belum dirating oleh user 4. Pertama, rumus Euclidean Distance harus diketahui untuk dapat membuat rumus persamaan yang akan digunakan. Berikut merupakan rumus dari Euclidean Distance.

$$
d\left(\left[x_{1}, x_{2}, \ldots, x_{n}\right],\left[y_{1}, y_{2}, \ldots, y_{n}\right]\right)=\sqrt{\sum_{i=1}^{n}\left(x_{i}-y_{i}\right)^{2}}
$$

Pada permasalahan sistem rekomendasi, $x$ dan $y$ merupakan nilai rating dari dua pelanggan yang berbeda untuk n (berapa) buah barang, sehingga dari persamaan (1) dapat diketahui jarak nilai rating dari kedua pelanggan. Semakin besar Euclidean Distance maka semakin diketahui bahwa jarak dari nilai yang diberikan semakin besar, sebaliknya semakin kecil Euclidean Distance maka jarak dari nilai yang diberikan dari pelanggan semakin kecil atau semakin mirip. Dari rumus persamaan (1) dan tabel 1 tersebut maka dapat dibuat Euclidean Distance sebagai persamaan (2). Berikut adalah rumus Euclidean Distance untuk aplikasi penjualan tiket kelas pelatihan.

$$
d(x, y)=\sqrt{\sum_{i=1}^{2}(x i-y i)^{2}}
$$

Sebagai contoh persamaan (2) dapat digunakan untuk menghitung Euclidean Distance dari User 1 dan User 4, maka penjelasan dari rumus tersebut yaitu :

$\boldsymbol{d}(\boldsymbol{x}, \boldsymbol{y})=$ Euclidean distance dari User 1 dan User 4

n = banyak kelas yang telah diberi rating oleh User 4

$x \boldsymbol{x}=$ nilai rating yang diberikan User 1 pada film $i$

$\boldsymbol{y} \boldsymbol{i}=$ nilai rating yang diberikan User 4 pada film $i$ 
Dari rumus dan penjelasan tersebut maka dapat dibuat perhitungan Euclideance Distance untuk User 1 dan User 4 seperti berikut.

$$
\begin{aligned}
d(x, y) & =\sqrt{ }(3-3)^{2}+(5-4)^{2} \\
& =\sqrt{ } 1 \\
& =1
\end{aligned}
$$

Dengan rumus ini maka didapatkan jarak nilai dari semua pelanggan ke pelanggan 4 seperti pada tabel II berikut ini.

TABEL III

EUCLIDEAN DISTANCE RATING ANTARA USER 4 DAN USER LAIN.

\begin{tabular}{|l|l|}
\hline $\begin{array}{c}\text { Euclideance } \\
\text { Distance }\end{array}$ & \multicolumn{1}{|c|}{ User 4 } \\
\hline User 1 & 1 \\
\hline User 2 & 1,4 \\
\hline User 3 & 1 \\
\hline
\end{tabular}

Langkah Selanjutnya yaitu menghitung kemiripan antara ketiga pelanggan dengan pelanggan ke-empat. Untuk menghitung kemiripan rating antara pelanggan maka dibutuhkan rumus seperti berikut.

$$
\operatorname{sim}(x, y)=\frac{1}{1+d(x, y)}
$$

Dengan rumus persamaan (3) ini maka dapat dihitung persamaan dari kemiripan antara pelanggan 4 dan pelanggan lainnya. Sebagai contoh nilai kemiripan antara User 1 dan User 4 yaitu $1 /(1+1)=0,5$. Dengan begitu maka didapatkan hasil kemiripan rating antara pelanggan 4 dengan pelanggan lainnya dan dapat dibuat ke dalam tabel seperti berikut.

TABEL III

NILAI KEMIRIPAN RATING ANTARA USER 4 DAN USER LAIN

\begin{tabular}{|l|l|}
\hline \multicolumn{1}{|c|}{ Similiarity } & \multicolumn{1}{|c|}{ User 4} \\
\hline User 1 & 0,5 \\
\hline User 2 & 0,42 \\
\hline User 3 & 0,5 \\
\hline
\end{tabular}

Langkah berikutnya adalah membuat urutan rekomendasi dengan menggunakan tabel III tersebut. Caranya yaitu dengan mengalikan antara nilai kemiripan rating dengan rating dari setiap kelas pelatihan yang sudah dinilai oleh User 1, User 2 dan User 3. Selanjutnya pada tabel IV akan dilakukan perhitungan dalam melihat nilai rekomendasi User 4 untuk Kelas Seni Batik Tulis.
Berikutnya pada tabel $\mathrm{V}$ dilakukan perhitungan untuk nilai rekomendasi User 4 untuk Kelas Tingkatan Omset Toko Online Anda, sedangkan untuk perhitungan nilai rekomendasi User 4 untuk Kelas Free Training iOS dapat dilihat pada tabel VI. Tabel IV, V dan VI dapat ditunjukkan sebagai berikut.

TABEL IV

Nilai ReKomendasi USER 4 UNTUK Kelas SENi BatiK TUlis

\begin{tabular}{|l|l|l|l|}
\hline \multicolumn{4}{|c|}{ Rekomendasi Kelas Seni Batik Tulis (KBT) } \\
\hline Pelanggan & $\begin{array}{c}\text { Nilai } \\
\text { Kemiripan } \\
\text { dengan User } \\
\mathbf{4}\end{array}$ & $\begin{array}{c}\text { Rating } \\
\text { untuk } \\
\text { Kelas KBT } \\
\text { Rekomendasi }\end{array}$ & $\begin{array}{c}\text { Nilai } \\
\text { User } 1\end{array}$ \\
\hline User 2 & 0,5 & 3 & 1,5 \\
\hline User 3 & 0,5 & 5 & 2,1 \\
\hline
\end{tabular}

TABEL V

Nilai REKOMENDASI USER 4 UNTUK KELAS TingKatKan OMSET TOKO ONLINE ANDA

\begin{tabular}{|c|c|c|c|}
\hline \multicolumn{3}{|c|}{ Rekomendasi Kelas Tingkatkan Omset Toko Online Anda } \\
(OTO) \\
\hline Pelanggan & $\begin{array}{c}\text { Nilai } \\
\text { Kemiripan } \\
\text { dengan User } \\
\mathbf{4}\end{array}$ & $\begin{array}{c}\text { Rating } \\
\text { untuk } \\
\text { Kelas } \\
\text { OTO }\end{array}$ & $\begin{array}{c}\text { Nilai } \\
\text { Rekomendasi }\end{array}$ \\
\hline User 1 & 0,5 & 4 & 2 \\
\hline User 2 & 0,42 & 4 & 1,68 \\
\hline User 3 & 0,5 & 3 & 1,5 \\
\hline
\end{tabular}

TABEL VI

NILAI REKOMENDASI USER 4 UNTUK KELAS FREE TRAINING IOS

\begin{tabular}{|l|l|l|l|}
\hline \multicolumn{4}{|c|}{ Rekomendasi Kelas Free Training iOS (FTi) } \\
\hline Pelanggan & $\begin{array}{c}\text { Nilai } \\
\text { Kemiripan } \\
\text { dengan User } \\
\mathbf{4}\end{array}$ & $\begin{array}{c}\text { Rating } \\
\text { untuk } \\
\text { Kelas Fti } \\
\text { Rekomendasi }\end{array}$ & $\begin{array}{c}\text { Nilai } \\
\text { Rekomendas }\end{array}$ \\
\hline User 1 & 0,5 & 2 & 1 \\
\hline User 2 & 0,42 & 1 & 0,42 \\
\hline User 3 & 0,5 & 3 & 1,5 \\
\hline \multicolumn{3}{|c|}{ Total Nilai Rekomendasi } \\
\hline
\end{tabular}


Dari ketiga tabel rekomendasi tersebut dapat disimpulkan bahwa urutan dari rekomendasi tertinggi sampai yang terendah bisa didapatkan dari total nilai rekomendasi dengan urutan kelas Seni Batik Tulis tertinggi, kemudian kelas Tingkatkan Omset Toko Online Anda, dan terakhir yaitu kelas Free Training iOS.

\section{HASIL DAN PEMBAHASAN}

Setelah melalui berbagai tahapan dalam perancangan aplikasi dan perhitungan metode untuk menerapkan sistem rekomendasi pada aplikasi maka berikutnya akan dibahas hasil aplikasi yang telah dibuat. Berikut merupakan beberapa dari interface aplikasi yang dibuat sebagai hasil perancangan yang telah dibahas sebelumnya.

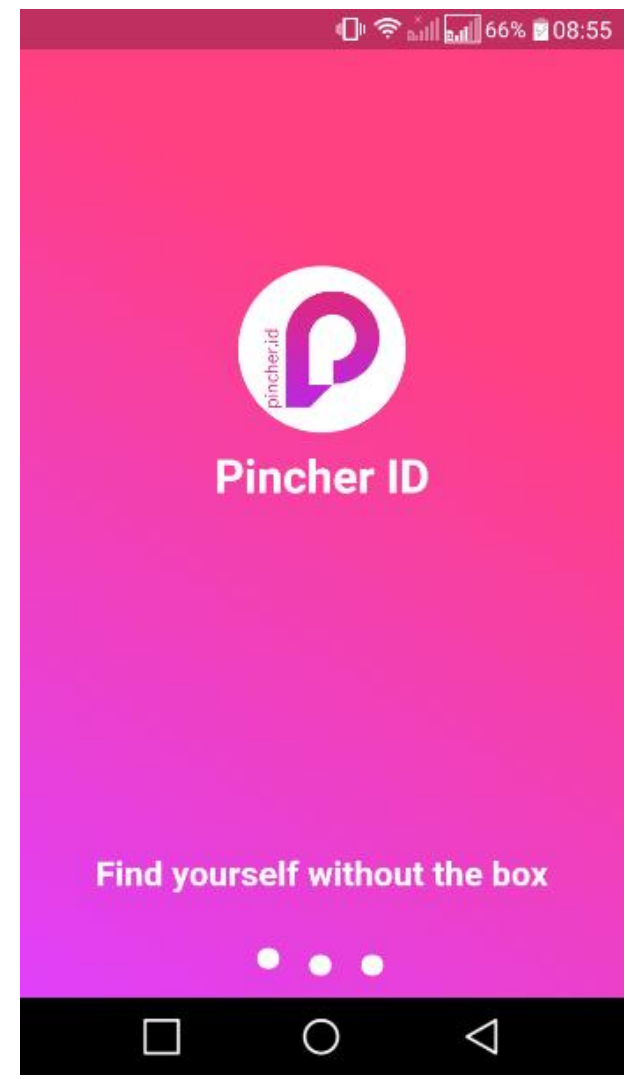

Gambar 10. Tampilan Splash Screen

Gambar 10 merupakan tampilan splash screen aplikasi, tampilan ini muncul saat aplikasi dibuka pertama kali. Tampilan splash screen ini memberitahu user bahwa aplikasi sedang ada dalam proses untuk menjalankan aplikasi.

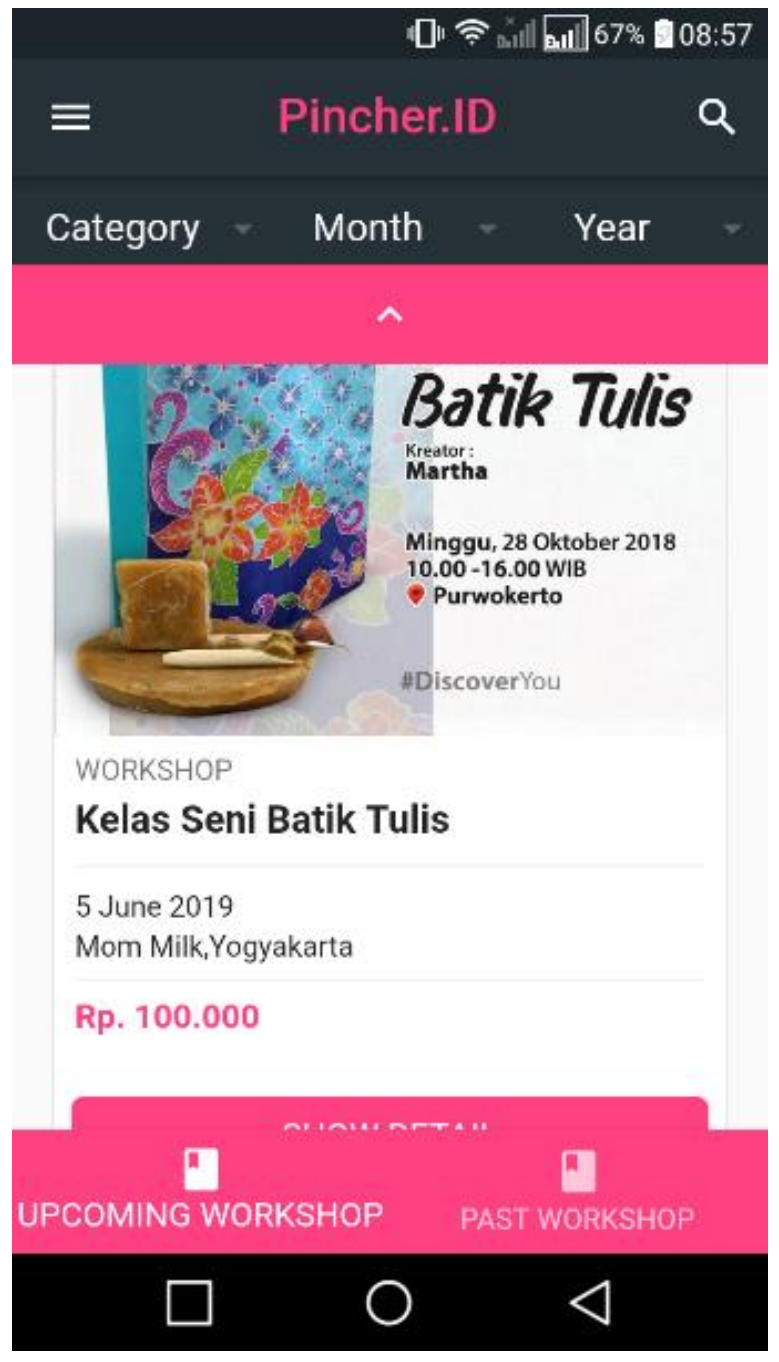

Gambar 11. Tampilan Home Screen

Gambar 11 merupakan tampilan halaman utama yang berisi daftar kelas pelatihan yang tersedia pada aplikasi. Halaman utama ini juga menyediakan menu pengurutan kelas untuk mengurutkan kelas pelatihan berdasarkan kategori, bulan atau tahun untuk memudahkan pengguna mencari kelas yang diinginkan. 


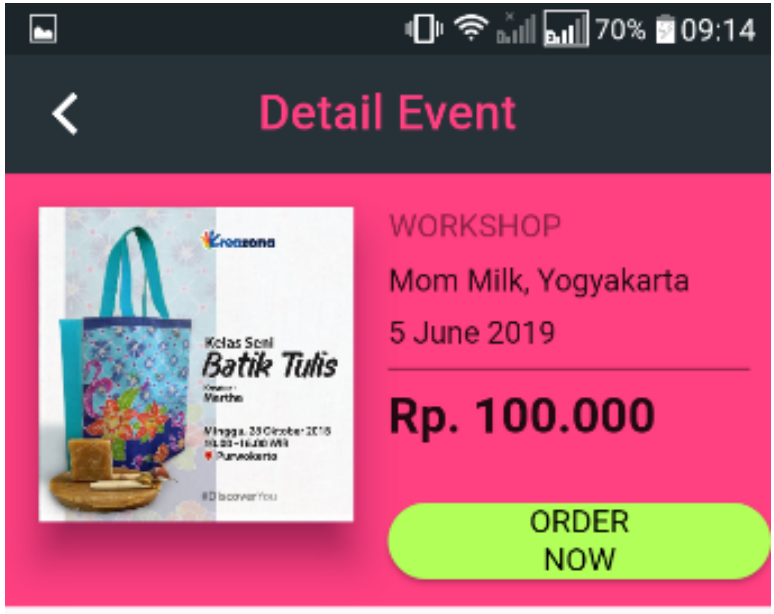

Kelas Seni Batik Tulis

Membeli dan mengenakan berbagai macam produk yang berbahan dasar kain batik sudah ngga asing lagi.

Apalagi, kini batik terkenal banget \&amp; penggunaannya ngga hanya untuk pakaian tradisional aja loh, tapi berbagai produk popular sekarang mulai terhias batik, mulai dari sepatu, tas, ikat pinggang, sampai hiasan rambut. Tentu aja hal ini membuat batik semakin terkenal dan dekat di hati kalangan muda.

Nah, buat Kamu yang penasaran banget sama jenis-jenis batik yang bisa diwujudkan jadi herhanai nrndıl nimana kalaı kamı

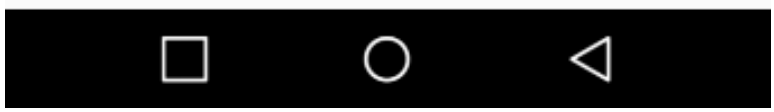

Gambar 12. Tampilan Class Detail

Gambar 12 adalah tampilan halaman rincian kelas, halaman ini merupakan halaman bagi pengguna untuk melihat informasi kelas pelatihan secara terperinci. Pada halaman ini terdapat nama kelas, tempat akan diadakan, tanggal diadakan, harga tiket, dan deskripsi kelas yang disediakan sebagai informasi. Halaman ini juga menyediakan tombol untuk memesan tiket kelas dan tombol untuk memberikan nilai pada kelas.
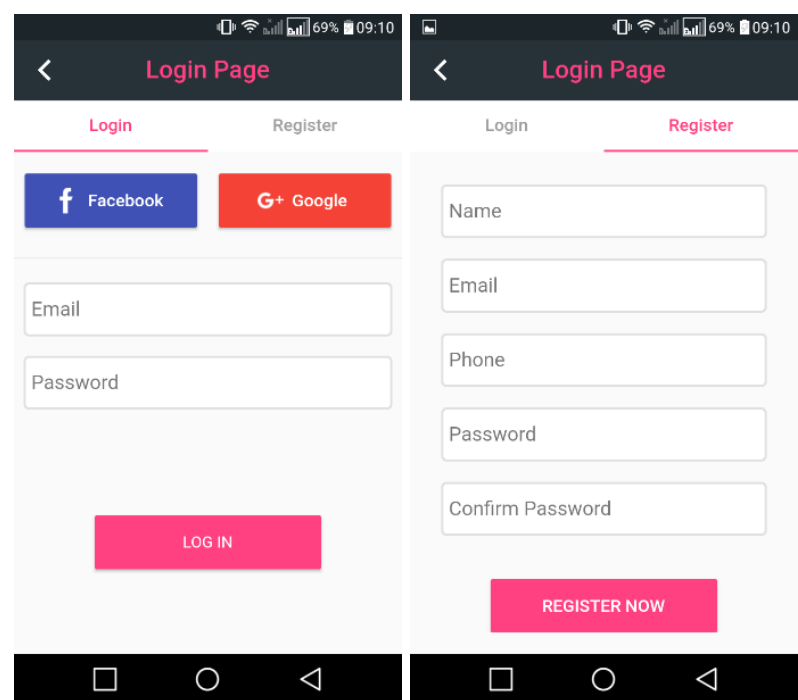

$\square$

O

$\triangleleft$

Gambar 13. Tampilan Login Page.

Gambar 13 adalah tampilan login, pada halaman ini terdapat 2 menu untuk pelanggan yaitu login atau masuk sebagai member dan register untuk mendaftar sebagai member. Menu login ini berfungsi untuk mengkonfirmasi atau memberikan identitas pengguna agar dapat melakukan transaksi pemesanan tiket kelas melalui aplikasi.
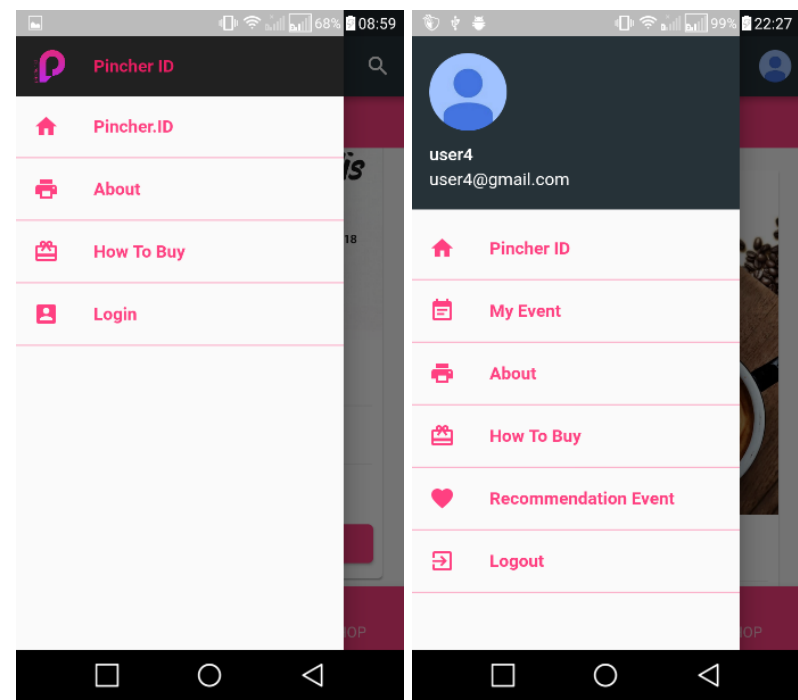

Gambar 14. Tampilan Side Navigation Menu.

Pada gambar 14 merupakan tampilan menu navigasi samping yang berfungsi sebagai navigasi untuk perpindahan antar halaman pada aplikasi pemesanan tiket kelas pelatihan. Pada gambar kiri merupakan menu saat sebelum login dan gambar kanan merupakan menu setelah login. 


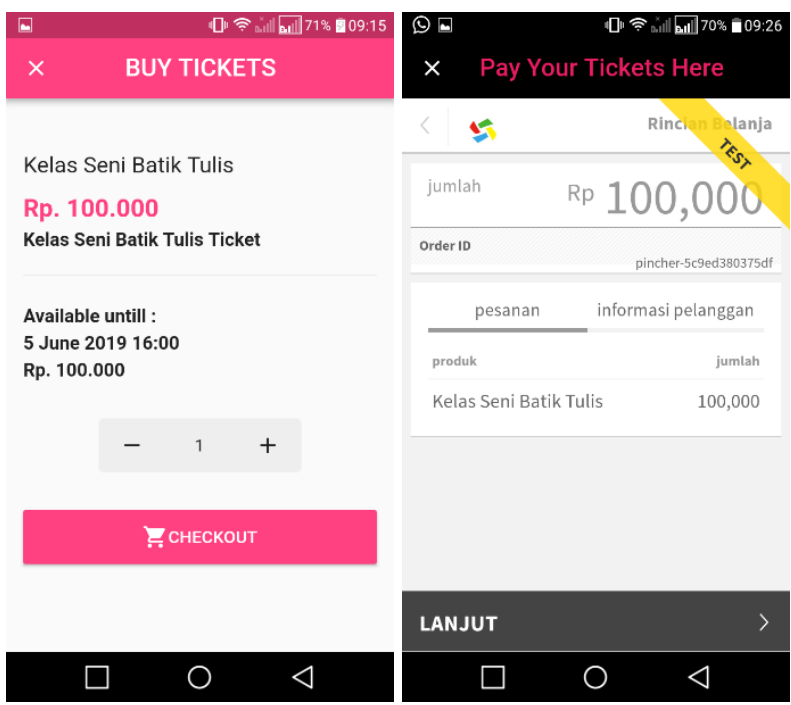

Gambar 15. Tampilan Halaman Pemesanan Tiket.

Gambar 15 adalah tampilan dari halaman pemesanan tiket. Pada halaman ini pengguna dapat menentukan berapa tiket yang akan dipesan untuk kelas yang akan diikuti dan kemudian menentukan metode pembayaran tiket untuk melakukan transaksi.
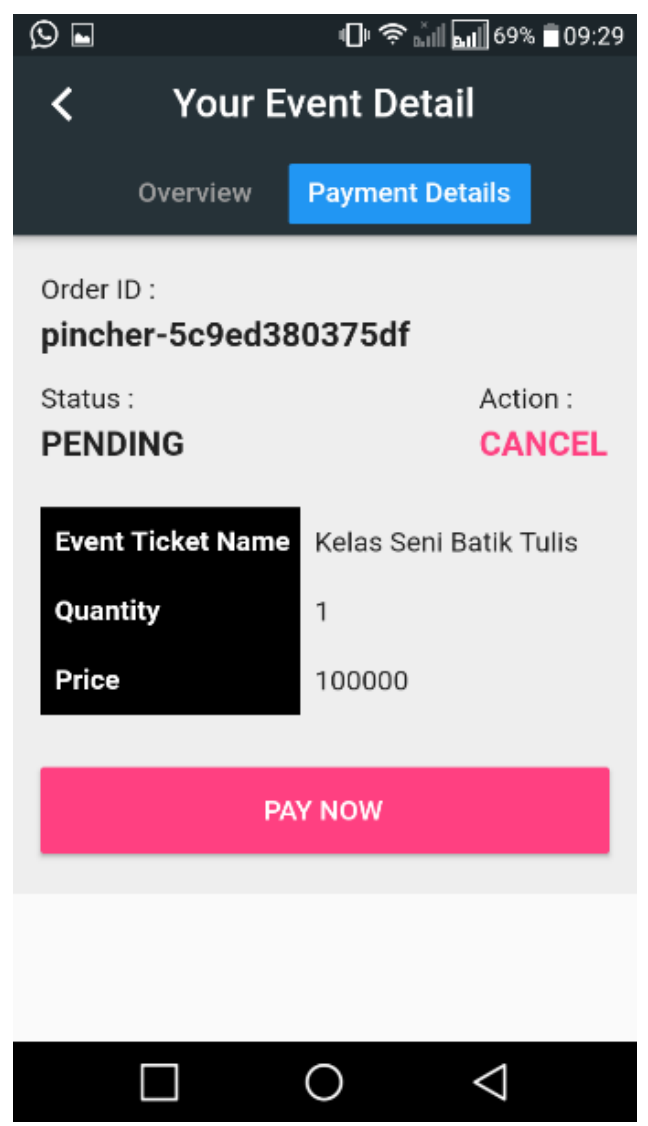

Gambar 16. Tampilan My Event Detail.
- Gambar 16 merupakan tampilan kelas yang sudah dipesan pelanggan. Halaman ini dapat dilihat pada navigasi my event. Pada halaman ini pelanggan dapat melihat informasi kelas dari tab Overview dan melihat informasi status pemesanan tiket dari tab Payment Details. Pada tab Payment Details ini pelanggan dapat melakukan pembatalan pemesanan tiket atau meneruskan proses transaksi pembayaran tiket lewat aplikasi.
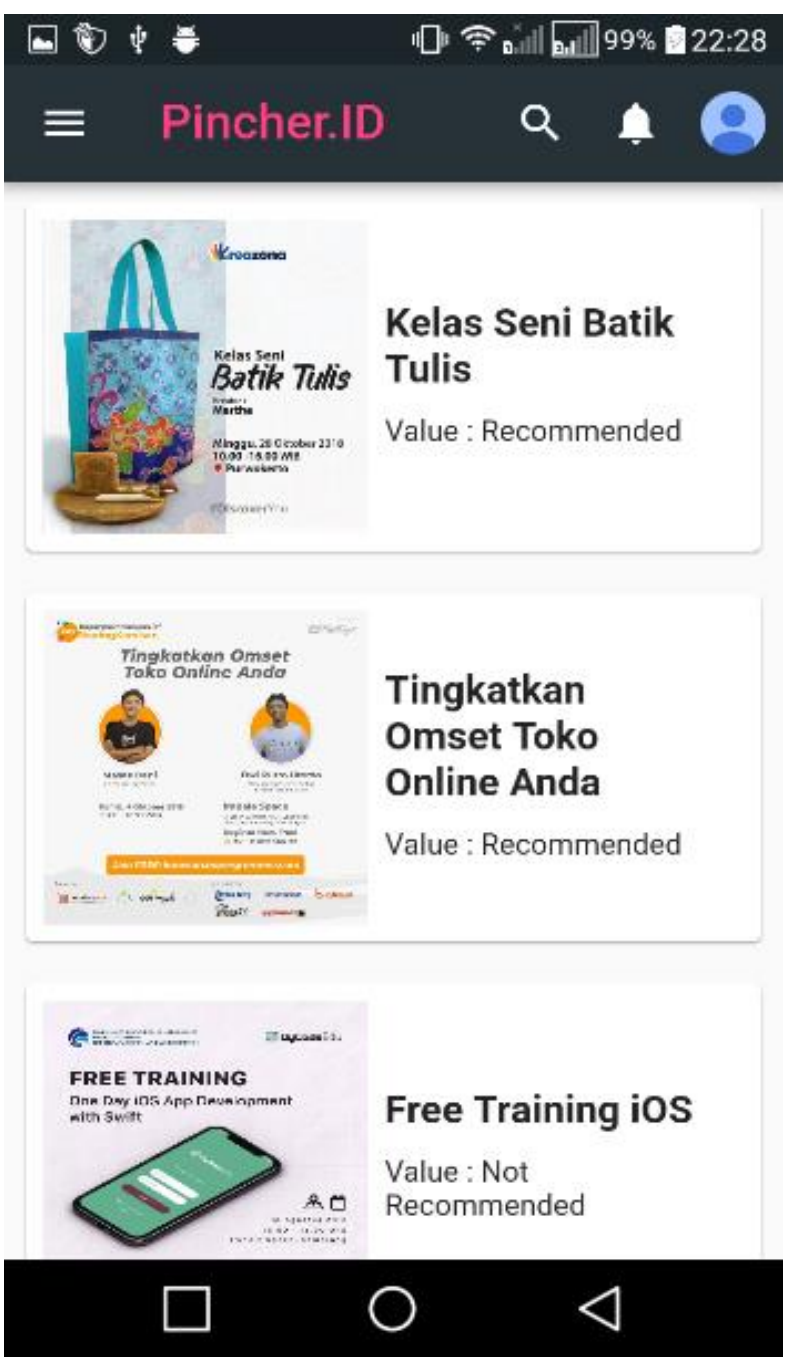

Gambar 17. Tampilan Halaman Rekomendasi.

Gambar 17 adalah tampilan halaman rekomendasi kelas yang memberikan rekomendasi kelas untuk pelanggan. Pada halaman ini ditampilkan rekomendasi kelas pelatihan yang belum pernah dinilai oleh pelanggan yang bersangkutan. Terdapat 3 value yang diberikan yaitu Very Recommended, Recommended dan Not Recommended.

Membahas tentang penerapan sistem rekomendasi yang sudah dirancang sebelumnya, berikut merupakan kode program untuk menghitung rekomendasi kelas pelatihan. 
KODE PROGRAM III

REKOMENDASI KELAS

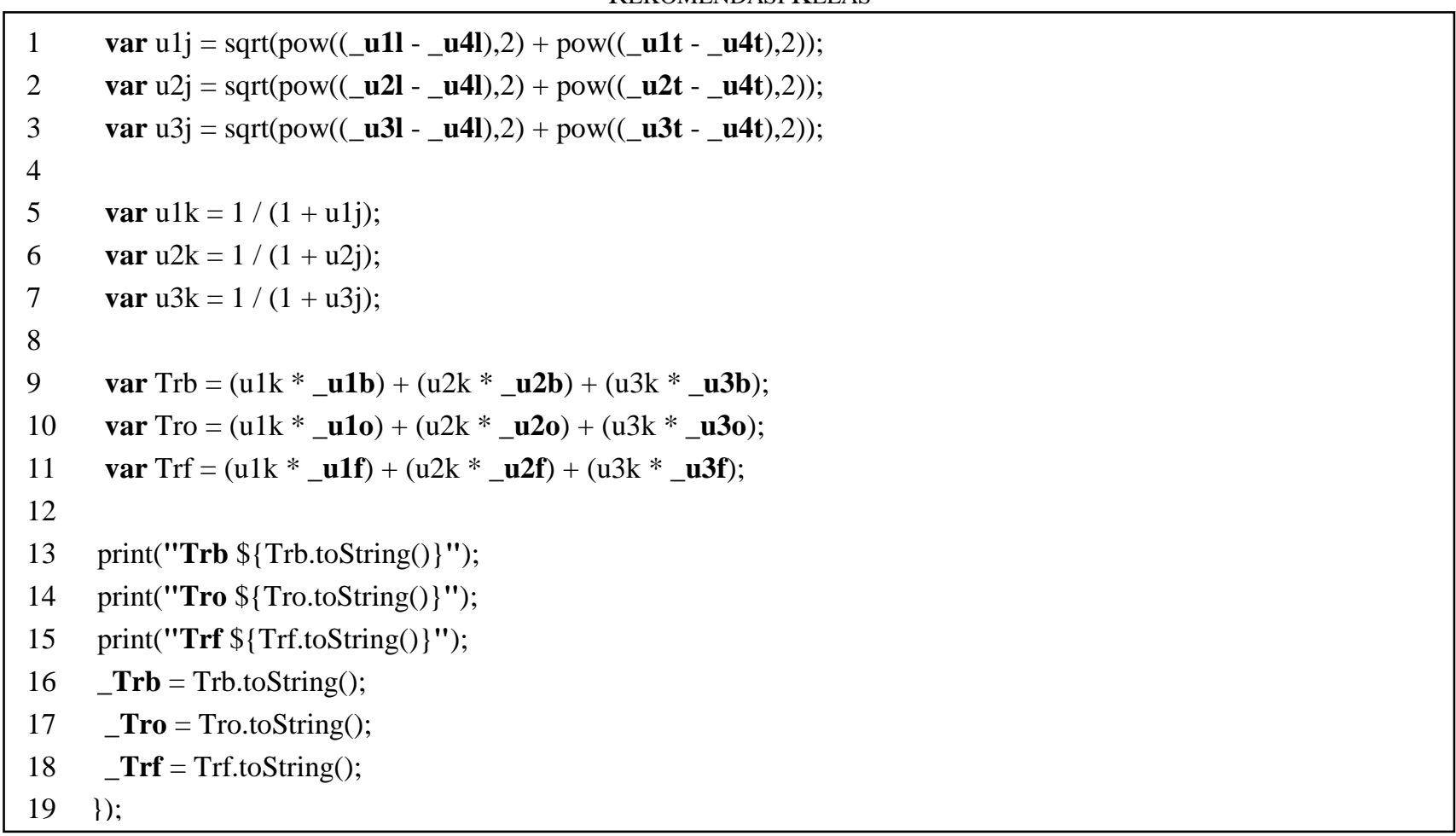

Pada Kode Program I tersebut dapat dijelaskan bahwa baris 1 - 3 merupakan kode untuk menghitung Euclideance Distance dari rating yang sudah dimasukkan 3 pengguna kepada satu pengguna yang belum memasukkan nilai yaitu user 1, user 2, dan user 3 untuk user 4. Baris 5-7 digunakan untuk menghitung Similiarity (kemiripan) yang diambil dari hasil perhitungan Euclideance Distance antara user 4 dengan pengguna lainnya dengan rumus $1 /(1+$ nilai Euclideance Distance). Baris 9 - 11 adalah lagkah terakhir untuk menghitung rekomendasi tiap kelas dengan mengambil nilai kemiripan rating kemudian mengalikan dengan nilai rating yang diberikan tiap pengguna selain $u s e r$ 4 lalu menambahkan nilai yang telah dikalikan untuk mendapatkan total hasil rekomendasi pada kelas masing masing. Setelah nilai diperhitungkan maka hasil rekomendasi dimunculkan ke dalam konsol dengan perintah print seperti tampak pada baris 13 - 19. Hasil dari perhitungan tersebut ditampilkan ke dalam console status Flutter seperti pada gambar berikut.

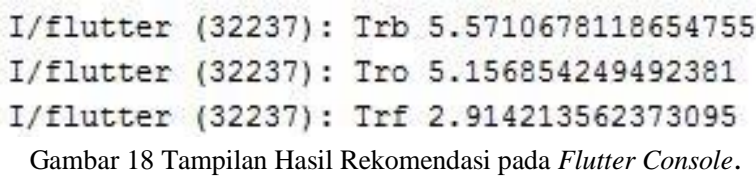

Dari semua tahapan yang sudah dilalui, baik dari perancangan, penerapan metode, dan hasil yang diperoleh dari perancangan atau hasil aplikasi, maka dilakukan uji coba pada aplikasi untuk mengetahui aplikasi dapat berjalan sesuai ketentuan atau tidak. Berikut merupakan hasil uji coba alpha yang dimasukkan ke dalam Tabel VII.

TABEL VII

Pengujian Alpha Aplikasi Penjualan Tiket Kelas Pelatihan

\begin{tabular}{|l|l|l|l|l|l|}
\hline No. & Titik Pengujian & \multicolumn{1}{|c|}{ Data Input } & \multicolumn{1}{c|}{$\begin{array}{c}\text { Data } \\
\text { Output }\end{array}$} & \multicolumn{1}{|c|}{ Hasil Uji Coba } & $\begin{array}{c}\text { Status } \\
\text { Uji }\end{array}$ \\
\hline 1 & $\begin{array}{l}\text { Menampilkan kelas } \\
\text { pelatihan }\end{array}$ & - & $\begin{array}{l}\text { Daftar kelas } \\
\text { pelatihan }\end{array}$ & $\begin{array}{l}\text { Aplikasi dapat menampilkan kelas } \\
\text { yang disediakan dari database }\end{array}$ & Clear \\
\hline 2 & Uji halaman login & $\begin{array}{l}\text { Email dan } \\
\text { Password }\end{array}$ & - & $\begin{array}{l}\text { Aplikasi dapat memverifikasi } \text { email } \\
\text { dan password yang telah terdaftar } \\
\text { dan memberikan umpan balik yang } \\
\text { tepat jika terjadi kesalahan }\end{array}$ & Clear \\
\hline
\end{tabular}




\begin{tabular}{|l|l|l|l|l|l|}
\hline & & & pengisian data & \\
\hline 3 & $\begin{array}{l}\text { Uji halaman } \\
\text { register }\end{array}$ & $\begin{array}{l}\text { Nama, Email, } \\
\text { Telepon, Password } \\
\text { dan Konfirmasi } \\
\text { Password }\end{array}$ & - & $\begin{array}{l}\text { Aplikasi dapat memverifikasi } \\
\text { email, password dan konfirmasi } \\
\text { password jika terjadi kesalahan } \\
\text { pengisian data atau terdapat data } \\
\text { kosong }\end{array}$ & Clear \\
\hline 4 & $\begin{array}{l}\text { Pemesanan tiket } \\
\text { kelas pelatihan }\end{array}$ & $\begin{array}{l}\text { Jumlah tiket, } \\
\text { Metode } \\
\text { pembayaran }\end{array}$ & - & $\begin{array}{l}\text { Aplikasi dapat mengirimkan } \\
\text { jumlah tiket pemesanan, melakukan } \\
\text { perhitungan harga, dan } \\
\text { memverifikasi metode pembayaran } \\
\text { pelanggan }\end{array}$ & Clear \\
\hline 5 & $\begin{array}{l}\text { Menampilkan } \\
\text { status pemesanan } \\
\text { tiket kelas } \\
\text { pelatihan }\end{array}$ & - & $\begin{array}{l}\text { Daftar kelas } \\
\text { pelatihan } \\
\text { terpesan }\end{array}$ & $\begin{array}{l}\text { Aplikasi dapat memberikan umpan } \\
\text { balik berupa tampilan rincian kelas } \\
\text { yang belum maupun sudah terbayar } \\
\text { dengan mengambil data dari } \\
\text { database }\end{array}$ & Clear \\
\hline 7 & $\begin{array}{l}\text { Pembatalan tiket } \\
\text { kelas pelatihan } \\
\text { kelas pelatihan }\end{array}$ & Cancel order & - & $\begin{array}{l}\text { Aplikasi dapat membatalkan } \\
\text { pesanan tiket yang belum terbayar }\end{array}$ & Clear \\
\hline
\end{tabular}

Berdasarkan pada Tabel VII tersebut dapat disimpulkan bahwa aplikasi penjualan tiket kelas pelatihan tersebut memenuhi kriteria untuk digunakan oleh client atau pelanggan untuk memesan tiket kelas yang disediakan oleh Pincher. Setelah uji coba melalui alpha testing tersebut maka aplikasi dapat melakukan uji coba selanjutnya yaitu beta testing dengan menguji aplikasi ke pengguna nyata. Pengujian beta ini dilakukan dengan memberikan kuesioner kepada 10 pelanggan pengguna aplikasi. Berikut adalah pertanyaan kuesioner yang diberikan:

1. Tampilan aplikasi yang dibangun sudah bagus

2. Aplikasi mudah digunakan.

3. Fungsi aplikasi sebagai media dalam pemesanan tiket kelas pelatihan sudah sesuai dan berjalan dengan baik.

4. Sistem rekomendasi pada aplikasi membantu menentukan kelas yang ingin diikuti.

5. Anda puas dengan hasil aplikasi penjualan tiket kelas pelatihan berbasis mobile.

Skala yang diberikan untuk tiap pertanyaan yaitu $1-5$.

- Sangat Setuju

$\begin{array}{ll}= & 5 \\ = & 4 \\ = & 3 \\ = & 2 \\ = & 1\end{array}$

TABEL VIII

JUMLAH JAWABAN KUESIONER

\begin{tabular}{|l|l|l|l|l|l|}
\hline \multirow{3}{*}{ Soal } & \multicolumn{6}{|c|}{ Jumlah Jawaban } \\
\cline { 2 - 7 } & 1 & 2 & \multicolumn{1}{|c|}{3} & 4 & 5 \\
\hline 1 & - & - & 2 & 3 & 5 \\
\hline 2 & - & 2 & 3 & 3 & 2 \\
\hline 3 & - & - & 1 & 3 & 6 \\
\hline 4 & - & 1 & 2 & 4 & 3 \\
\hline 5 & - & - & 1 & 4 & 5 \\
\hline
\end{tabular}

Tabel VIII adalah data jawaban 10 pengguna yang telah dirangkum. Dari Tabel VIII tersebut hasil dapat dimasukkan ke dalam skala Likert. Skala Likert digunakan untuk menghitung persentase dari masing - masing kategori pertanyaan. Rumus persamaan skala Likert yaitu sebagai berikut.

Indeks Kesesuaian Kasar $(\%)=($ Total Skor $/$ Skor Maksimum) x $100 \%$ 
TABEL IX

Hasil Persentase Kuesioner

\begin{tabular}{|c|c|c|c|c|c|c|c|}
\hline \multirow[t]{2}{*}{ Pertanyaan } & \multicolumn{5}{|c|}{$\begin{array}{l}\text { Skala Penilaian * Frekuensi } \\
\text { Kemunculan Data }\end{array}$} & \multirow[t]{2}{*}{$\begin{array}{l}\text { Total } \\
\text { Skor }\end{array}$} & \multirow[t]{2}{*}{$\begin{array}{l}\text { IKK } \\
(\%)\end{array}$} \\
\hline & 1 & 2 & 3 & 4 & 5 & & \\
\hline 1 & - & - & 6 & 12 & 25 & 43 & $86 \%$ \\
\hline 2 & - & 4 & 9 & 12 & 10 & 35 & $70 \%$ \\
\hline 3 & - & - & 3 & 12 & 30 & 45 & $90 \%$ \\
\hline 4 & - & 2 & 6 & 16 & 15 & 39 & $78 \%$ \\
\hline 5 & - & - & 3 & 16 & 25 & 44 & $88 \%$ \\
\hline
\end{tabular}

Dengan Tabel IX tersebut dapat disimpulkan bahwa $86 \%$ responden menyatakan tampilan aplikasi penjualan tiket kelas pelatihan berbasis mobile sudah bagus, $70 \%$ responden menyatakan aplikasi mudah digunakan, 90\% menyatakan fungsi aplikasi sebagai media dalam pemesanan tiket kelas pelatihan sudah sesuai dan berjalan dengan baik, $78 \%$ menyatakan sistem rekomendasi pada aplikasi membantu menentukan kelas yang ingin diikuti dan $88 \%$ menyatakan puas dengan hasil aplikasi penjualan tiket kelas pelatihan berbasis mobile.

\section{KESIMPULAN}

Dari hasil uji coba yang telah dilakukan pada aplikasi penjualan tiket kelas pelatihan berbasis mobile, maka dapat disimpulkan bahwa aplikasi penjualan tiket kelas pelatihan berbasis mobile ini telah memenuhi standar ketentuan untuk digunakan oleh publik dan dapat membantu memudahkan pengguna dalam mencari kegiatan pembelajaran yang diinginkan melalui kelas pelatihan yang disediakan oleh aplikasi. Dengan kelengkapan fasilitas atau fitur yang disajikan dan tampilan yang fresh, aplikasi dapat digunakan oleh pengguna dengan efisien, mudah dan nyaman. Selain mudah dan nyaman digunakan aplikasi penjualan tiket kelas pelatihan ini juga menyediakan fitur menarik yaitu perekomendasian kelas pelatihan, dengan merekomendasikan kelas yang banyak diminati kepada [14] pelanggan yang belum pernah mengikuti kelas pelatihan dan belum mengetahui kelas pelatihan tersebut, pelanggan dapat dengan mudah mengetahui kelas mana yang paling menarik untuk pelanggan.

\section{DAFTAR PUSTAKA}

[1] Dharma,Yoga Adi dan Tanone, Radius. MSME Recommendation Application using Collaborative Filtering Method and Realtime Database (Case Study: Salatiga City). International Conference on Electrical Enginering and Computer Science (ICECOS). pp 361-366, 2018.

[2] Yulianti, Endah dan Rochman, E, F. Sistem Informasi Pemesanan Tiket Travel Berbasis Mobile Android. Universitas Kanjuruhan Malang. 2014.

[3] Witono, Timotius. Aplikasi Pemesanan Tiket Bioskop Berbasis Mobile. Jurnal Sistem Informasi, Vol.7, No.2, pp 143 - 151, September 2012

[4] Kurniawan, Arif. Sistem Rekomendasi Produk Sepatu Dengan Menggunakan Metode Collaborative Filtering. Seminar Nasional Teknologi Informasi dan Komunikasi, 2016.

[5] Dzumiroh, Lisniati. Penerapan Metode Collaborative Filtering Menggunakan Rating Implisit pada Sistem Perekomendas Pemilihan Film di Rental VCD. JURNAL ITSMART, Vol 1, No 2, pp 54-59, Desember, 2012.

[6] Sari, Syandra. Aplikasi Rekomendasi Film menggunakan Pendekatan Collaborative Filtering dan Euclidean Distance sebagai ukuran kemiripan rating. Seminar Nasional Teknologi Informasi dan Komunikasi Terapan (SEMANTIK). pp 135-140, 2015.

[7] Dian, Muhar. (2018). Tutorial Flutter \#1: Pengenalan dan Persiapan Pemrograman Mobile dengan Flutter. [Online]. Tersedia: https://www.petanikode.com/flutter-linux/.

[8] Anindita. (2015). Pengenalan Web Service. [Online]. Tersedia: https://aninditasaktiaji.com/pengenalan-web-service/.

[9] Widad, Muhamad Faisal. Sistem Informasi Penjualan Berbasis Android Di Toko Busana Faisal Collection (SIPITON). Program Studi Sistem Informasi. Fakultas Teknik dan Ilmu Komputer. Universitas Komputer Indonesia. Bandung. 2017.

[10] Badriyah, Tessy. Sistem Rekomendasi Content Based Filtering Menggunakan Algoritma Apriori. Konferensi Nasional Sistem Informasi. pp 554-559, 2018.

[11] Uyun, Shofwatul. Item Collaborative Filtering untuk Rekomendasi Pembelian Buku secara Online. JUSI Vol. 1, No. 1, pp 63-70, Februari, 2011.

[12] Nastia, Niken N.N. Penerapan Euclidean Distance pada Pengenalan Pola Citra Sidik Jari. Program Studi Statistika Fakultas MIPA. Universitas Islam Indonesia. 2018.

[13] Sugiyono. Metode Penelitian Kuantitatif Kualitatif dan R\&D Bandung: Alfabeta. 2010 